\title{
Administration of pig relaxin to beef heifers 4 or 7 days pre partum*
}

\author{
R. W. Caldwell, R. A. Bellows $\dagger$, J. A. Hall and R. V. Anthony \\ Department of Animal Sciences, University of Missouri, Columbia, Missouri 65211, USA; and \\ †USDA-Agricultural Research Service, Fort Keogh Livestock and Range Research Laboratory, \\ Miles City, Montana 59301, USA
}

\begin{abstract}
Summary. Crossbred beef heifers $(\mathrm{N}=36)$ were assigned to one of three treatment groups: untreated controls $(C ; N=15)$; Group $R 4$, treated with pig relaxin $(1.0 \mathrm{mg}$ i.m.) 4 days pre partum $(\mathrm{N}=11)$; or Group $\mathrm{R} 7$, treated with pig relaxin $(1.0 \mathrm{mg}$ i.m. 7 days pre partum $(\mathrm{N}=10$ ). Bioactivity of the pig relaxin (UMC-R-P8) was determined by the mouse interpubic ligament assay to be $\geq 3000 \mathrm{U} / \mathrm{mg}$, both before and after the experiment was conducted. Peripheral serum immunoreactive relaxin values were $7 \cdot 5$, $3.4,2 \cdot 5$, and $1.5 \mathrm{ng} / \mathrm{ml}$ at $2,4,6$ and $8 \mathrm{~h}$ after injection of relaxin, respectively. Gestation lengths were $282.9 \pm 1 \cdot 1,285.5 \pm 1.3$ and $285.6 \pm 1.5$ days for Groups $C$, $\mathrm{R} 4$ and $\mathrm{R} 7$ (C vs R4 + R7; $P \simeq 0.08$ ). Calving difficulty score (1 to 4 ) tended to be greater $(P \simeq 0.08)$ for Group $\mathrm{R} 4$ and $\mathrm{R} 7$ heifers $(\mathrm{C} v s \mathrm{R} 4+\mathrm{R} 7 ; 1.3 \pm 0.24$ vs $1.75 \pm 0.28+2.04 \pm 0.32$ ), but the incidences of dystocia and retained placentae were not influenced by treatment $(P \geq 0 \cdot 10)$. The mean concentration and concentration profile of daily serum progesterone, oestradiol-17 $\beta$, dihydroprostaglandin F-2 $\alpha$ and relaxin were not affected by treatment from 6 days pre partum through 2 days post partum. Cervical diameter, cervical softness score, pelvic measurements, and vulva opening length during the periparturient period were not affected $(P \geq 0 \cdot 10)$ by treatment, but all of these characteristics changed over time $(P \leqslant 0.01)$, relative to calving. We conclude that i.m. administration of pig relaxin $(\geq 3000 \mathrm{U})$ does not effectively alter periparturient characteristics of beef heifers. Discrepancies between these results and those reported for intracervical administration cannot be readily explained.
\end{abstract}

Keywords: relaxin; beef heifers; pre partum; dystocia

\section{Introduction}

Calf death caused by dystocia is a major factor that contributes to a reduction in net calf crop. The need for the cattle industry to maximize the total production of a cow requires that she must first calve at 2 years of age. However, dystocia is most prevalent in primiparous heifers calving at 2 years of age (Brinks et al., 1973). A major factor contributing to dystocia is a disproportion in the size of the fetus to the pelvic area of the dam (Bellows et al., 1971a; Rice \& Wiltbank, 1972; Price \& Wiltbank, 1978b). Calf birth weight is directly related and pelvic area is inversely related to the incidence of dystocia in cattle (Bellows et al., 1969; Price \& Wiltbank, 1978b). Other factors associated with calving difficulty are: age and breed of dam, breed and genotype of sire, sex and shape of calf, length of gestation, pre-partum nutrition of the dam, vulval stenosis and uterine inertia (Price \& Wiltbank, 1978a).

Relaxin is a polypeptide hormone produced primarily during pregnancy, and is produced by various reproductive organs of many species (Anderson, 1987). Relaxin is involved in cervical

*Reprint requests to: Dr Russell V. Anthony. 
dilatation (Downing \& Sherwood, 1985), relaxation of the pubic symphysis (Steinetz et al., 1960), inhibition of uterine contractility (Porter, 1971), and stimulation of uterine growth (Vasilenko \& Mead, 1987). Intracervical administration of pig relaxin to primigravid beef heifers 4 or 5 days before expected parturition induced cervical dilatation and increased pelvic area (Perezgrovas \& Anderson, 1982; Musah et al., 1986a, b). Additionally, when pig relaxin was administered with cloprostenol or dexamethasone 10 days pre partum, the incidence of retained placentae was reduced (Musah et al., 1987b) when compared to cloprostenol or dexamethasone treatment alone. It has been suggested (Musah et al., 1987a) that relaxin may have a direct or indirect luteolytic effect, but Caldwell et al. (1990) indicated that pig relaxin by itself was unable to induce parturition in beef cows 10 days pre partum when administered intramuscularly.

The objectives of this research were to determine the effectiveness of intramuscular pig relaxin administration to first-calf heifers in reducing the incidence of dystocia, and to determine its influence on physical and hormonal changes during the periparturient period.

\title{
Materials and Methods
}

\begin{abstract}
Animals. Thirty-six Hereford $(\mathrm{H})$ or Brahman $(\mathrm{Br})$ sired crossbred heifers were mated by artificial insemination to a single Gelbvieh sire, to calve at approximately 2 years of age. The 2-year-old heifers were maintained on pasture until 30 days before their expected date of parturition, at which time they were moved to observation lots and provided a corn silage-based diet ad libitum. Expected parturition was determined to be 285 days of gestation based on performance data of the sire.
\end{abstract}

Relaxin purification. Pig relaxin was purified from late-pregnant pig ovaries by the methods of Caldwell et al. (1990). Biological activity of the purified relaxin (UMC-R-P8) was determined both before and after experimental use in cattle, by the mouse interpubic ligament assay (Steinetz et al., 1960), using 20 mice per dose and NIH-R-P1 pRLX $(3000 \mathrm{U} / \mathrm{mg}$ ) as the reference standard. Pooled data (from before and after experimental use) from the bioassay were analysed for parallelism of the dose-response curves and relative potencies by the methods of Bliss (1952). The relative potency of UMC-R-P8 was determined to be $\geq 3000 \mathrm{U} / \mathrm{mg}$, and its dose-response curve was not different $(P \geq 0 \cdot 10)$ from that of NIH-R-P1 (slope $=1 \cdot 49 ; \lambda=0 \cdot 11$ ).

Experimental design and data collection. At 30 days before expected parturition, the heifers were randomly assigned within heifer breed $(\mathrm{H}$ or $\mathrm{Br})$ to one of three treatment groups. One group $(\mathrm{C} ; \mathrm{N}=15)$ served as untreated control animals; a second group ( $\mathrm{R} 4 ; \mathrm{N}=11$ ) received $1.0 \mathrm{mg}$ pig relaxin (UMC-R-P8) intramuscularly (i.m.) in phosphate-buffered saline (PBS) 4 days before expected parturition; and a third group ( $7 ; \mathrm{N}=10$ ) received $1.0 \mathrm{mg}$ pig relaxin (UMC-R-P8) i.m. in PBS 7 days before expected parturition. Daily blood samples, physical measurements and scores were collected on all heifers beginning 10 days before expected parturition, within $2 \mathrm{~h}$ of calving and through 2 days post partum. All of the following measurements and scores were obtained by a single individual and without knowledge of treatment assignment. Pelvic measurements were obtained by the methods of Bellows et al. (1971b). External length of the vulva opening was measured using a sliding caliper, and cervical diameter was estimated by rectal palpation. Cervical softness was scored from 1 (firm and non-pliable) to 4 (soft and very pliable) via rectal palpation. Additionally, blood samples were collected from one heifer in each of Groups R4 and R7 every $2 \mathrm{~h}$, beginning immediately before treatment with relaxin and continuing for $8 \mathrm{~h}$ after treatment to ascertain the clearance rate of relaxin after i.m. administration.

At parturition calving difficulty was scored (Bellows et al., 1971a) from 1 (no difficulty) to 4 (extreme difficulty or Caesarean section), and calf vigour was scored on a scale of 1 (alive and vigorous) to 3 (dead). Within $2 \mathrm{~h}$ of parturition, calf birth weight and maternal measurements and scores were determined. The placenta was classified as being retained if it had not been expelled within $24 \mathrm{~h}$ of parturition. Daily blood collection and maternal measurements continued until 2 days post partum, at which time the heifers and their calves were returned to pasture.

Hormone analyses. Daily blood samples were collected from a coccygeal vessel into non-heparinized tubes. The blood samples were maintained on ice until centrifugation at $1500 \mathrm{~g}$ for $2 \mathrm{~h}$. Resulting serum was decanted and stored at $-20^{\circ} \mathrm{C}$ until analysed for serum progesterone, oestradiol-17 $\beta, 15$-keto-13,14-dihydro-prostaglandin F-2 $\alpha$ (PGFM) and relaxin.

Concentrations of progesterone in $100 \mu \mathrm{l}$ samples of non-extracted serum were determined using a Diagnostic Products Corp. (Los Angeles, CA, USA) radioimmunoassay (RIA) kit. The standard curve ranged from $4.0 \mathrm{pg} /$ tube $(93.3 \pm 1.8 \% \mathrm{~B} / \mathrm{Bo})$ to $4.0 \mathrm{ng} /$ tube $(7.2 \pm 1.2 \% \mathrm{~B} / \mathrm{Bo})$. Intra-assay and interassay coefficients of variation were $10.1 \%(\mathrm{~N}=6)$ and $9.7 \%(\mathrm{~N}=18)$, respectively, for two pools of spiked ovariectomized cow serum $(26.1 \mathrm{ng} / \mathrm{ml}$ and $4.92 \mathrm{ng} / \mathrm{ml}$ ). Concentrations of serum oestradiol were determined by the RIA described by Kesler et al. (1977) in 
$100 \mu \mathrm{l}$ samples. Average extraction (diethyl ether) efficiency was $95.6 \%$, but samples were not adjusted for procedural losses. Intra-assay and inter-assay coefficients of variation were $11.4 \%(\mathrm{~N}=10)$ and $21 \cdot 1 \%(\mathrm{~N}=20)$, respectively, for a pool of spiked ovariectomized cow serum $(9.6 \mathrm{pg} / \mathrm{ml})$. Serum PGFM concentrations were determined on $200 \mu \mathrm{l}$ samples (non-extracted) using the RIA described by Zollers et al. (1989). Concentrations of PGFM in a pool of ovariectomized cow sera, spiked with PGFM $(3 \cdot 2 \mathrm{ng} / \mathrm{ml})$, at 50,100 and $200 \mu \mathrm{l}$ doses were determined to estimate intra-assay and inter-assay coefficients of variation. The intra-assay and inter-assay coefficients of variation were $9 \cdot 2 \%(\mathrm{~N}=15)$ and $18 \cdot 2 \%(\mathrm{~N}=30)$, respectively.

Relaxin concentrations were measured with an homologous RIA as described by Musah et al. (1987a). Heifer serum samples $(200$ and $400 \mu \mathrm{l}$ ) or pig relaxin standards (UMC-R-P8; $0.01,0.025,0.05,0 \cdot 10,0.25,0.50,1.00$, and $2.00 \mathrm{ng} /$ tube in $0.05 \mathrm{M}-\mathrm{PBS}-1 \% \mathrm{BSA}$ ) were quantified in duplicate by the double-antibody RIA. Monotyrosylated relaxin (Schwabe, 1983) was iodinated to a specific activity of $78 \mu \mathrm{Ci} / \mu \mathrm{g}$ by the chloramine-T procedure (Hunter \& Greenwood, 1962) and used at 25000 c.p.m./tube (100 $\mu 1 ; 0.05$ M-PBS-1\% BSA). Rabbit antiporcine relaxin antiserum (Dual Rabbit $\mathbf{R}_{6}$ obtained from Dr B. G. Steinetz, New York University, Tuxedo, NY) was added to all tubes to a final titre of 1:300 000 in 0.05 M-PBS- $6 \%$ normal rabbit serum (NRS), except total count and non-specific binding tubes. Non-specific binding tubes received $0.05 \mathrm{M}$-PBS-6\% NRS, and all tubes were adjusted to $800 \mu \mathrm{l}$ with $0.05 \mathrm{M}$ PBS-1 $\%$ BSA before incubation at $4^{\circ} \mathrm{C}$ for $24 \mathrm{~h}$. After incubation, $200 \mu \mathrm{l}$ sheep-antirabbit antiserum (diluted 1:16 with $0.05 \mathrm{M}$-PBS-1\% BSA) was added to all tubes, except total count tubes, and incubated for $24 \mathrm{~h}$ at $4^{\circ} \mathrm{C}$. The precipitated relaxin-antibody complex was harvested by centrifugation at $3000 \mathrm{~g}$ for $30 \mathrm{~min}$, the supernatant was aspirated, and the precipitate counted in a $\gamma$-counter.

The maximum binding of the antibody was $29 \cdot 3 \pm 4.98 \%$, and non-specific binding was $3.48 \pm 0.56 \%$. Intra- and inter-assay coefficients of variation were determined to be $7 \cdot 12 \%(n=6)$ and $8.93 \%(n=18)$, respectively, for a pool of ovariectomized cow serum spiked with pig relaxin $(1.08 \mathrm{ng} / \mathrm{ml})$ and assayed in 50,100 and $200 \mu \mathrm{l}$ samples. Accuracy and precision were evaluated by the addition of pig relaxin (UMC-R-P8) to ovariectomized cow sera at doses (in duplicate) of $0.01,0.025,0.05,0 \cdot 10,0 \cdot 25,0.50,1.00$, and $2.00 \mathrm{ng} / 200 \mu \mathrm{l}$ serum (Fig. 1). Immunoreactive relaxin was undetectable in a pool of late-pregnant cow serum assayed in samples of 10, 25, 50, 75, 100, 150, 200, 300 and $400 \mu 1$.

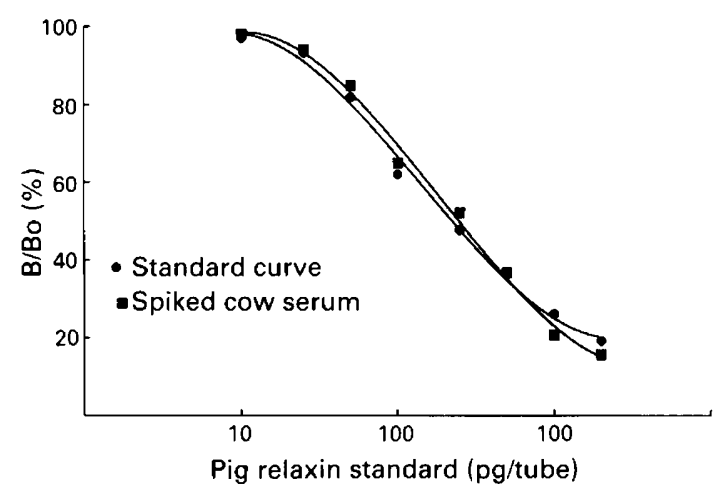

Fig. 1. Dose-response curves for pig relaxin standards (UMC-R-P8) and for sera from ovariectomized cows spiked with relaxin. The relaxin standards or spiked ovariectomized cow sera $(200 \mu \mathrm{l})$ contained $0 \cdot 01,0 \cdot 025,0 \cdot 05,0 \cdot 10,0 \cdot 25,0 \cdot 50,1 \cdot 00$ or $2 \cdot 00 \mathrm{ng} /$ tube.

Statistical analysis. Data were analysed by least-square analysis of variance using the General Linear Model procedures of Statistical Analysis Systems (SAS, 1982). The model included the main effects of treatment (orthogonal contrasts of $\mathrm{C} v s \mathrm{R} 4+\mathrm{R} 7$ and $\mathrm{R} 4 v s \mathrm{R} 7$ ), heifer breed ( $\mathrm{H}$ or $\mathrm{Br}$ ), calf sex (male or female), and the two- and three-way interactions. The response variables were calf birth weight, calving difficulty score, calf vigour score and gestation length. Incidences of calving difficulty and retained placenta were analysed by routine $\chi^{2}$ methods.

Daily measures (from 6 days pre partum to 2 days post partum) of cervical diameter and score, pelvic measures, vulva length and hormone concentrations were analysed by least-squares analysis of variance (SAS, 1982), with a split-plot in time analysis as described by Gill \& Hafs (1971). Data obtained earlier than 6 days pre partum were not included in the analysis because the no. of heifers/group became too low. The whole-plot main effects were treatment (C vs R4 + R7 and R4 vs R7), heifer breed ( $\mathrm{H}$ or $\mathrm{Br}$ ), calf sex (male or female) and the two- and three-way interactions, and were tested by the whole-plot error mean square. Day relative to calving was the sub-plot main effect and was interacted with all whole-plot main effects. The sub-plot regressions were tested by the sub-plot residual mean square. Orthogonal contrasts of C vs R4 + R7 and R4 vs R7 were fitted for both the whole-plot effect of treatment and the subplot regression. 


\section{Results}

\section{Treatment with relaxin}

Heifers assigned to Groups R4 and R7 received treatment 4 or 7 days, respectively, before expected parturition. Actual elapsed times from treatment to calving were $4.81 \pm 1.3$ and $6.86 \pm 1.33$ days respectively.

Blood samples were collected $0,2,4,6,8$ and $24 \mathrm{~h}$ after relaxin administration from one heifer in each of Groups R4 and R7 and their respective serum relaxin values are presented in Fig. 2. Serum relaxin appeared to reach maximum values $2 \mathrm{~h}$ after relaxin administration, decreased to half-maximal values by $4 \mathrm{~h}$ after treatment, and was undetectable by $24 \mathrm{~h}$ after treatment.

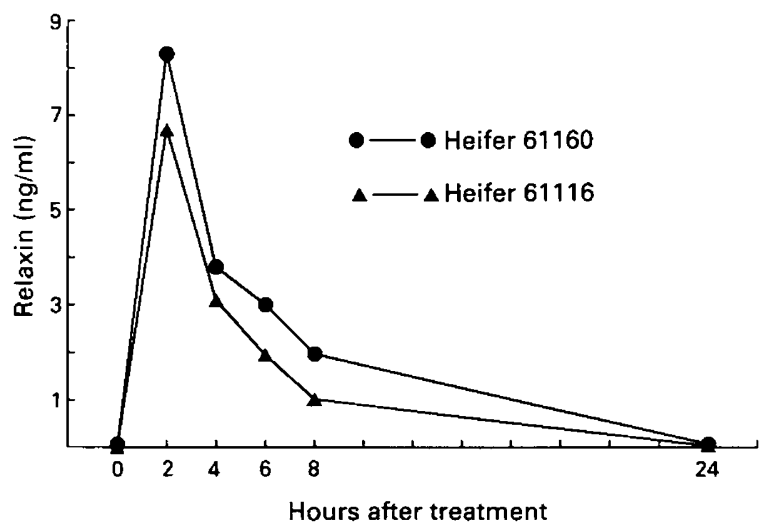

Fig. 2. Serum concentrations of relaxin after i.m. administration of $1.0 \mathrm{mg}$ pig relaxin. Heifer 61116 was treated on Day 4 pre partum and Heifer 61160 on Day 8 pre partum.

\section{Daily hormone analyses}

As shown in Fig. 3, there were no differences $(P \geq 0 \cdot 10)$ in mean hormone concentrations due to the main effects of treatment, heifer breed or calf sex, nor were there any significant $(P \geq 0 \cdot 10)$ two- or three-way interactions. All hormone profiles, except that of relaxin, were characterized by a significant $(P \leqslant 0.01)$ cubic sub-plot regression for time. Serum relaxin did not have a significant linear, quadratic or cubic response over time $(P \geq 0 \cdot 10)$, indicating that the serum relaxin profile was not statistically different from a horizontal line equivalent to the detection limits of the assay. These daily samples were collected immediately before treatment on the day of treatment for Group R4 and R7 heifers, and serum concentrations were undetectable by $24 \mathrm{~h}$ after treatment (Fig. 2). The profiles of all hormones measured were not influenced $(P \geq 0 \cdot 10)$ by treatment, breed or sex, and therefore the data presented in Fig. 3 were pooled accordingly.

\section{Daily physical measurements}

As shown in Fig. 4, all four physical measurements changed over time relative to calving and were characterized by a cubic regression $(P \leqslant 0 \cdot 01)$, but were not influenced $(P \geq 0 \cdot 10)$ by relaxin treatment and the data were pooled accordingly (Fig. 4).

Pelvic area stayed relatively constant until the day of calving when it increased, but it then appeared to decline during the 2 days post partum that measurements were obtained (Fig. 4). Relaxin treatment had no effect on pelvic height and width measurements $(P \geq 0 \cdot 10)$ or on these 

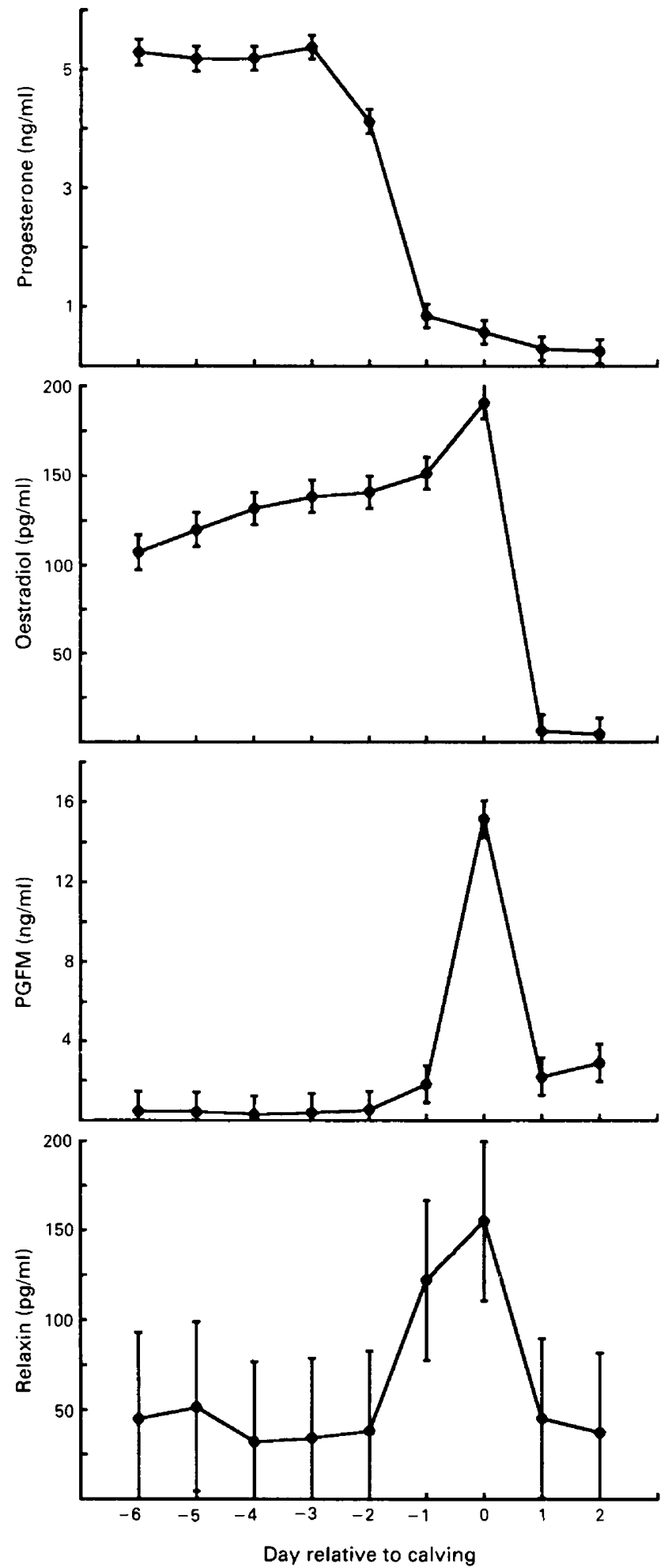

Fig. 3. Daily serum concentrations of hormones from 6 days pre partum through 2 days post partum. No differences existed $(P \geq 0 \cdot 10)$ in hormone concentrations or concentration profiles due to treatment, heifer breed or calf sex, therefore the data were pooled accordingly. 


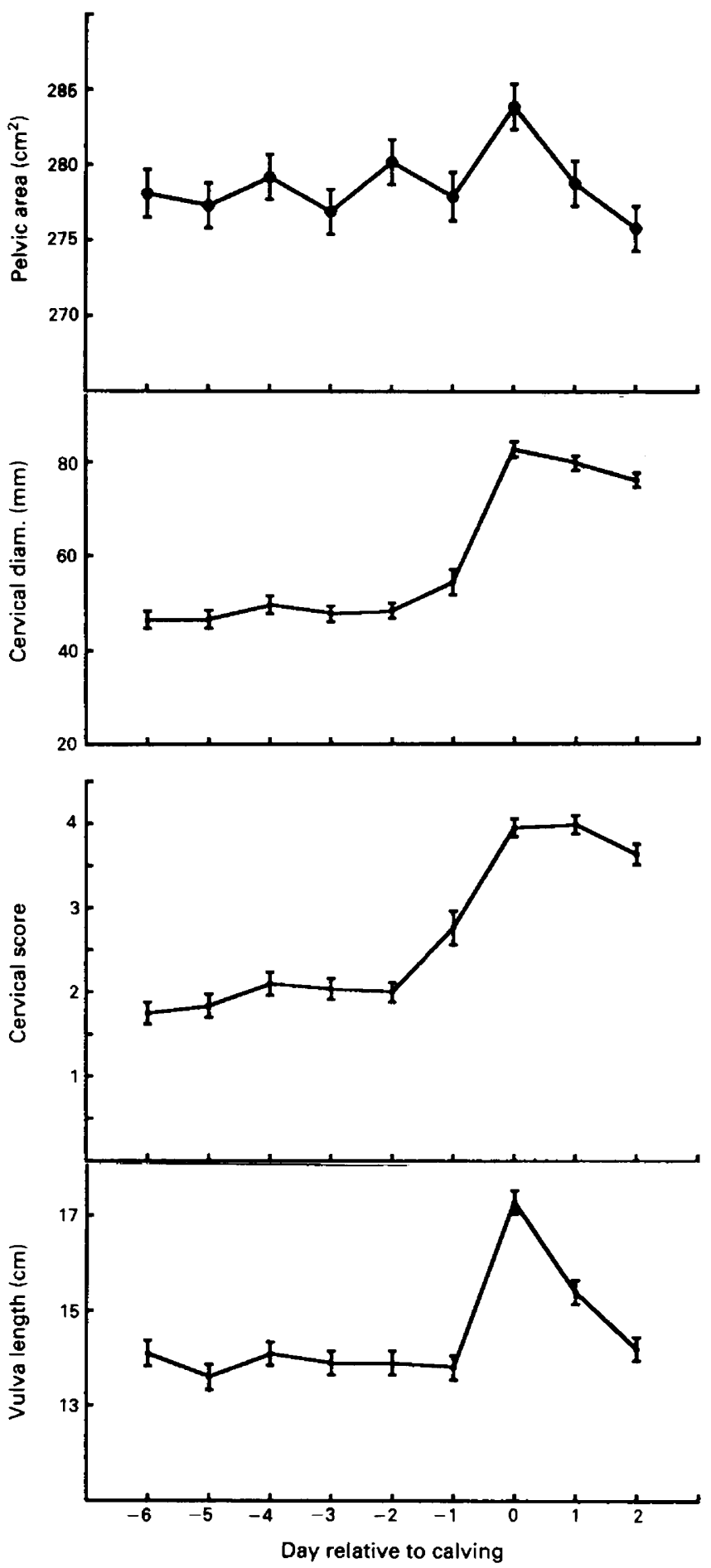

Fig. 4. Changes in various physical measurements from 6 days pre partum through 2 days post partum. None of the variables was influenced $(P \geq 0 \cdot 10)$ by relaxin treatment, but they all changed over time $(P \leq 0.01)$ relative to calving as a cubic function. Cervical softness was scored from 1 (firm and non-pliable) to 4 (soft and very pliable). 
measurements over time relative to calving. Pelvic height was characterized by a cubic sub-plot regression $(P \leqslant 0 \cdot 01)$, whereas pelvic width did not change over time significantly $(P \geq 0 \cdot 10)$ in a linear, quadratic or cubic fashion.

Cervical diameter and cervical softness score (Fig. 4) began to increase 1 day pre partum and reached maximal values on the day of calving. The statistical analysis indicated that there were no effects $(P \geq 0 \cdot 10)$ of treatment, heifer breed or calf sex on these two variables, nor were there any differences $(P \geq 0 \cdot 10)$ in their response over time due to treatment, heifer breed or calf sex. However, both cervical diameter and cervical softness score changed over time $(P \leqslant 0.01)$ as a cubic function (Fig. 4).

Brahman heifers had longer $(P \leqslant 0.05)$ length of the vulva opening $(15.2 \pm 0.43$ vs $13.7 \pm 0.40 \mathrm{~cm})$ than did $\mathrm{H}$ heifers, but this measurement was not affected by relaxin treatment or calf sex $(P \geq 0 \cdot 10)$. Vulva length (Fig. 4) appeared to remain relatively constant except on the day of calving when it increased approximately $3 \mathrm{~cm}$, and then decreased over the 2 days post partum. This change over time for vulva length was not influenced by relaxin treatment or calf sex, but was influenced $(P \leqslant 0.01)$ by breed of heifer.

\section{Calving data}

Data obtained at the time of calving, as influenced by treatment, are presented in Table 1 . Gestation length was estimated, based on performance data of the service sire, to be 285 days; however, actual gestation length tended to be shorter $(P \simeq 0.08)$ for Group $C$ heifers compared with those in Groups R4 and R7. Gestation length was not influenced by breed of heifer, but male calves tended $(P \simeq 0.07)$ to gestate longer than did female calves $(286.1 \pm 1.15$ vs $283.3 \pm 0.98$ days). Calf birth weight was not affected by relaxin treatment or heifer breed, but male calves were heavier $(P \leqslant 0.05)$ at birth than were female calves $(42.4 \pm 1.81$ vs $36.9 \pm 1.54 \mathrm{~kg})$. Calf vigour score (1 to 3 ) was not affected $(P \geq 0 \cdot 10)$ by treatment, heifer breed or calf sex.

Table 1. Least-squares means for data obtained at the time of calving

\begin{tabular}{lcccc}
\hline & \multicolumn{3}{c}{ Treatment } & Error \\
\cline { 2 - 4 } & $\begin{array}{c}\text { Group C } \\
(\mathrm{N}=15)\end{array}$ & $\begin{array}{c}\text { Group R4 } \\
(\mathrm{N}=11)\end{array}$ & $\begin{array}{c}\text { Group R7 } \\
(\mathrm{N}=10)\end{array}$ & $\begin{array}{c}\text { mean } \\
\text { square }\end{array}$ \\
\hline Gestation length (days) & 282.9 & 285.5 & 285.6 & 16.4 \\
Calf birth weight (kg) & 39.7 & 37.6 & 42.0 & 40.6 \\
Calf vigour score* & 1.08 & 1.25 & 1.17 & 0.33 \\
Calving difficulty score $\dagger$ & 1.31 & 1.75 & 2.04 & 0.77 \\
$\begin{array}{l}\text { Incidence of calving } \\
\text { difficulty (\%) }\end{array}$ & 20.0 & 45.4 & 60.0 & \\
$\begin{array}{l}\text { Incidence of retained } \\
\text { placentae (\%) }\end{array}$ & 0.0 & 9.1 & 10.0 & \\
\hline
\end{tabular}

\footnotetext{
*Calf vigour was scored from 1 (alive and vigorous) to 3 (dead).

†Calving difficulty was scored from 1 (no difficulty) to 4 (extreme difficulty or caesarean section).
}

Severity of calving difficulty (Table 1$)$ tended $(P \simeq 0.08)$ to be less for Group $C$ heifers when compared to Group R4 and R7 heifers, but the incidence of calving difficulty $(20.0 \mathrm{vs} 52.4 \%, \mathrm{C} v \mathrm{~s}$ $\mathrm{R} 4+\mathrm{R} 7)$ was not statistically different $(P \geq 0 \cdot 10)$. Neither heifer breed nor calf sex influenced $(P \geq 0 \cdot 10)$ severity of calving difficulty or the incidence of calving difficulty. The incidence of placentae being retained longer than $24 \mathrm{~h}$ post partum was not affected $(P \geq 0 \cdot 10)$ by treatment, heifer breed or calf sex. 


\section{Discussion}

Gestation length was not shortened by i.m. administration of pig relaxin 4 or 7 days before expected parturition as it was following intracervical administration of $1 \mathrm{mg}$ at 5 days before expected parturition (Musah et al., 1986a). Actually, gestation length tended $(P \simeq 0.08)$ to be longer for relaxin-treated heifers when compared with untreated controls in the present study. Gestation length was not affected when pig relaxin was administered by i.m. injection at 10 days before expected parturition (Caldwell et al., 1990), or when administered by i.m. injection or by intracervical infusion 4 days pre partum (Perezgrovas \& Anderson, 1982). In the present study, severity of calving difficulty also tended $(P=0 \cdot 08)$ to be greater in heifers receiving pig relaxin i.m., which is in contrast to the effects of pig relaxin given in conjunction with dexamethasone or cloprostenol (Musah et al., 1988) to induce parturition at 10 days pre partum. The contrast in results between the present study and those reported by Musah et al. (1986a, 1988) is not readily explicable, but may result from differences in the route of relaxin administration (i.m. $v s$ intracervical) and/or the proximity of treatment to the onset of labour.

Intramuscular injection of $1.0 \mathrm{mg}$ pig relaxin resulted in circulating relaxin concentrations of $\sim 7.5 \mathrm{ng} / \mathrm{ml}$ at $2 \mathrm{~h}$ after injection; these fell to $\sim 1.5 \mathrm{ng} / \mathrm{ml}$ at $8 \mathrm{~h}$ and became undetectable by $24 \mathrm{~h}$ after injection. Musah et al. (1987a) reported that plasma relaxin concentrations peaked at $3 \mathrm{~h}(23.1 \mathrm{ng} / \mathrm{ml})$ after i.m. administration and were undetectable by $6 \mathrm{~h}$ after injection whereas following infusion into the cervical os, plasma values peaked at $1 \mathrm{~h}(30.3 \mathrm{ng} / \mathrm{ml})$ and declined to baseline concentration by $24 \mathrm{~h}$ after infusion. Following relaxin administration by either route, Musah et al. (1987a) reported a transient decline in plasma progesterone and transient increases in plasma oestrone and oestradiol-17 $\beta$ concentrations. The relaxin concentrations attained in the present study and that of Musah et al. (1987a) did not approach the values observed near parturition in pigs (Sherwood et al., 1981). Whether there is a threshold concentration of circulatiing relaxin above which alteration of release of other hormones occurs cannot be presently answered, nor can it be answered whether there is a threshold concentration of relaxin that must be reached to hasten parturition. In the present study, there was no influence of pig relaxin treatment on the profile of daily serum concentrations of progesterone, oestradiol, PGFM or relaxin (Fig. 3) relative to calving, which is in agreement with Musah et al. (1986a). The serum concentration profiles of these hormones are consistent with earlier reports in cattle (Smith et al., 1973; Hunter et al., 1977).

Daily determinations of pelvic height, width and area were not affected by relaxin treatment. This finding is in contrast to reports by Musah et al. (1986a, b) following intracervical infusion of pig relaxin 5 days before expected parturition, but is in agreement with Perezgrovas \& Anderson (1982) for i.m. administration at 4 days pre partum. The contrast in results obtained for pelvic dimensions and area between the present study and those of Musah et al. (1986a, b) is not readily explicable, since we did observe significant changes due to time, heifer breed and calf sex.

Cervical diameter and softness score changed $(P \leqslant 0.01)$ over time respective to parturition but were not influenced by pig relaxin treatment, heifer breed or calf sex. Perezgrovas \& Anderson (1982) did not observe significant relaxin-induced changes of the cervix following i.m. administration. However, Perezgrovas \& Anderson (1982) and Musah et al. (1986a) report relaxin-induced changes in cervical dilatation after intracervical administration. Cervical diameter estimates were made by rectal palpation rather than by the device described by Perezgrovas \& Anderson (1982). It is possible that estimating cervical diameter by rectal palpation is not sufficiently sensitive to detect changes due to treatment, but insertion of a measuring device or infusion instrument into the cervix during the immediate pre-partum period could in itself induce cervical dilatation. Use of an intracervical device (Perezgrovas \& Anderson, 1982) to measure cervical dilatation may actually be measuring cervical extensibility. The effects of relaxin on cervical extensibility have been well documented for the rat (Downing \& Sherwood, 1985; Hwang \& Sherwood, 1988). Administration of $2 \mathrm{mg}$ highly purified pig relaxin into the posterior vaginal fornix (MacLennan et al., 1980) or into 
the cervical canal (Evans et al., 1983) has been reported to enhance cervical softening and dilatation in women. It is possible that the affinity of pig relaxin for the bovine relaxin receptor is low enough that i.m. administration of $1 \mathrm{mg}$ does not provide sufficient pig relaxin at the cervix to elicit a response in cattle, as does local administration within the cervix of cattle and humans.

In the present study, administration of pig relaxin during the pre-partum period did not effectively change the events of parturition in beef heifers. As yet, bovine relaxin and its role in the progression of parturition is essentially uncharacterized. Fields et al. (1980) reported the purification of bovine relaxin from corpora lutea of late-pregnant cows, but further characterization of the protein has not been reported. Anderson et al. (1982) measured immunoreactive relaxin in serum from late-pregnant heifers, using a pig relaxin RIA, and found relaxin concentrations to be $<200 \mathrm{pg} / \mathrm{ml}$ through 1 day pre partum and then rising abruptly to approximately $800 \mathrm{pg} / \mathrm{ml}$ on the day of parturition. A similar profile was found in the present study, using essentially an identical RIA, except that our peak concentrations were less (Fig. 3) than those reported by Anderson et al. (1982). The values we obtained for immunoreactive relaxin were below the detection limits of the assay except for the day of and the day preceding calving. Because the assays used by Anderson et al. (1982) and in the present study are both heterologous assays in regard to bovine relaxin, the reliability of these data is questionable. An accurate characterization of the structure of bovine relaxin and its secretion during the periparturient period is needed to delineate its role in parturition.

In conclusion, administration of $1.0 \mathrm{mg}$ pig relaxin $(\geq 3000 \mathrm{U} / \mathrm{mg}$ ) by i.m. injection 4 or 7 days before expected parturition did not change periparturient events in beef heifers, which agrees with the results of Perezgrovas \& Anderson (1982) who also used i.m. administration of pig relaxin but is in contrast to the findings of Musah et al. $(1986 \mathrm{a}, \mathrm{b})$ who used intracervical administration. An explanation of the cause of these variable results awaits further understanding of the physiological role of relaxin in cattle. Relaxin probably plays an important role during the periparturient period in cattle, but concise elucidation of this role will require further investigation and the characterization of bovine relaxin.

This is Contribution Journal Series Number 10983 from the Missouri Agricultural Experiment Station. We thank D. Phelps and A. Darling for technical support; M. Lewis for typing this manuscript; and Dr C. Schwabe and Dr B. G. Steinetz for generous gifts of tyrosylated-relaxin and anti-porcine relaxin antiserum, respectively.

\section{References}

Anderson, L.L. (1987) Regulation of relaxin secretion and its role in pregnancy. In Regulation of Ovarian and Testicular Function, pp. 421-463. Eds V. B. Mahesh, D. S. Dhindsa, E. Anderson \& S. P. Kalra. Plenum, New York.

Anderson, L.L., Perezgrovas, R., O'Byrne, E.M. \& Steinetz, B.G. (1982) Biological actions of relaxin in pigs and beef cattle. Ann. NY Acad. Sci. 380, $131-150$.

Bellows, R.A., Anderson, D.C. \& Short, R.E. (1969) Some factors associated with calving difficulty. J. Anim. Sci. 29(Suppl. 1), 184, abstr.

Bellows, R.A., Gibson, R.B., Anderson, D.C. \& Short, R.E. (1971a) Precalving body size and pelvic area relationships in Hereford heifers. J. Anim. Sci. 33, 455-457.

Bellows, R.A., Short, R.E., Anderson, D.C., Knapp, B.W. \& Pahnish, O.F. (1971b) Cause and effect relationships associated with calving difficulty and calf birth weight. J. Anim. Sci. 33, 407-415.
Bliss, C.I. (1952) The Statistics of Bioassay. Academic Press, New York.

Brinks, J.S., Olson, J.E. \& Carroll, E.J. (1973) Calving difficulty and its association with subsequent productivity in Herefords. J. Anim. Sci. 36, 11-17.

Caldwell, R.W., Whittier, J.C., Smith, M.F., Morrow, R.E. \& Anthony, R.V. (1990) Parturition in beef cows following administration of porcine relaxin at ten days prepartum. Theriogenology 33, 613-626.

Downing, S.J. \& Sherwood, O.D. (1985) The physiological role of relaxin in the pregnant rat. III. The influence of relaxin on cervical extensibility. Endocrinology 116, 1215-1220.

Evans, M.D., Dougan, M.B., Moawad, A.H., Evans, W.J., Bryant-Greenwood, G. \& Greenwood, F.C. (1983) Ripening of the human cervix with porcine ovarian relaxin. Am.J. Obstet. Gynecol. 147, 410-414.

Fields, M.J., Fields, P.A., Castro-Hernandez, A. \& Larkin, L.H. (1980) Evidence for relaxin in corpora lutea of late pregnant cows. Endocrinology 107, 869-876. 
Gill, J.L. \& Hafs H.D. (197I) Analysis of repeated measurements of animals. J. Anim. Sci. 33, 331-336.

Hunter, W.M. \& Greenwood, F.C. (1962) Preparation of iodine-131 labelled human growth hormone of high specific activity. Nature, Lond. 194, 495-496.

Hunter, J.T., Fairclough, R.J., Peterson, A.J. \& Welch, R.A.S. (1977) Foetal and maternal hormonal changes preceding normal bovine parturition. Acta endocr., Copenh. 84, 653-662.

Hwang, J.J. \& Sherwood, O.D. (1988) Monocional antibodies specific for rat relaxin. III. Passive immunization with monoclonal antibodies throughout the second half of pregnancy reduces cervical growth and extensibility in intact rats.. Endocrinology 123, 2486-2490.

Kesler, D.J., Garverick, H.A., Youngquist, R.S., Elmore, R.J. \& Bierschwal, C.J. (1977) Effect of days postpartum and endogenous reproductive hormones on GNRH-induced LH release in dairy cows. J. Anim. Sci. 46, 797-803.

MacLennan, A.H., Green, R.C., Byant-Greenwood, G.D., Greenwood, F.C. \& Seamark, R.F. (1980) Ripening of the human cervix and induction of labour with purified porcine relaxin. Lancet 1, 220-223.

Musah, A.I., Schwabe, C., Willham, R.L. \& Anderson, L.L. (1986a) Relaxin on induction of parturition in beef heifers. Endocrinology 118, 1476-1482.

Musah, A.I., Schwabe, C., Willham, R.L. \& Anderson, L.L. (1986b) Pelvic development as affected by relaxin in three genetically selected frame size of beef heifers. Biol. Reprod. 34, 363-369.

Musah, A.I., Schwabe, C. \& Anderson, L.L. (1987a) Acute decrease in progesterone and increase in estrogen secretion caused by relaxin during late pregnancy in beef heifers. Endocrinology 120, 317-324.

Musah, A.I., Schwabe, C., Willham, R.L. \& Anderson, L.L. (1987b) Induction of parturition, progesterone secretion, and delivery of placenta in beef heifers given relaxin with cloprostenol or dexamethasone. Biol. Reprod. 37, 797-803.

Musah, A.I., Schwabe, C., Willham, R.L. \& Anderson, L.L. (1988) Dystocia, pelvic and cervical dilation in beef heifers after induction of parturition with relaxin combined with cloprostenol or dexamethasone. Anim. Reprod. Sci. 16, 237-248.
Perezgrovas, R. \& Anderson, L.L. (1982) Effect of porcine relaxin on cervical dilation, pelvic area and parturition in beef heifers. Biol. Reprod. 26, 765-776.

Porter, D.G. (1971) The action of relaxin on myometrial activity in the guinea pig in vivo. J. Reprod. Fert. 26, $251-253$.

Price, T.D. \& Wiltbank, J.N. (1978a) Dystocia in cattle: A review and implications. Theriogenology 9, 195-219.

Price, T.D. \& Wiltbank, J.N. (1978b) Predicting dystocia in heifers. Theriogenology 9, 221-248.

Rice, L.E. \& Wiltbank, J.N. (1972) Factors affecting dystocia in beef heifers. J. Am. vet. med. Assoc. 161, 1348-1357.

SAS (1982) SAS User's Guide: Statistics. SAS Inst., Inc., Cary, NC.

Schwabe, C. (1983) N- $\alpha$-Formyl-Tyrosyl-Relaxin a reliable tracer for relaxin radioimmunoassay. Endocrinology 113, 814-815.

Sherwood, O.D., Nara, B.S., Welk, F.A., First, N.L. \& Rutherford, J.E. (1981) Relaxin levels in the maternal plasma of pigs before, during, and after parturition and before, during, and after suckling. Biol. Reprod. 25, 65-71.

Smith, V.G., Edgerton, L.A., Hafs, H.D. \& Convey, E.M. (1973) Bovine serum estrogens, progestins and glucocorticoids during late pregnancy, parturition and early lactation. J. Anim. Sci. 36, 391-396.

Steinetz, B.G., Beach, V.L., Kroc, R.L., Stasilli, N.R., Nussbaum, R.E., Nemith, P.J. \& Dun, R.K. (1960) Bioassay of relaxin using a reference standard: a simple and reliable method utilizing direct measurement of the interpubic ligament formation in mice. Endocrinology 67, 102-115.

Vasilenko, P. \& Mead, J.P. (1987) Growth-promoting effects of relaxin and related compositional changes in the uterus, cervix, and vagina of the rat. Endocrinology 120, 1370-1375.

Zollers, W.G., Garverick, H.A. \& Smith, M.F. (1989) Oxytocin-induced release of prostaglandin $F_{2}$ in postpartum beef cows: comparison of short versus normal luteal phases. Biol. Reprod. 41, 262-267.

Received 8 December 1989 